\title{
Allocating the Burden of Proof in Rule 60(b)(4) Motions to Vacate a Default Judgment for Lack of Jurisdiction
}

\author{
Ariel Waldman $\dagger$
}

Suppose a plaintiff files a civil complaint in federal court. Suppose further that the defendant learns of the action but believes that the court lacks personal jurisdiction. The defendant may choose to appear in the action and challenge the court's jurisdiction.'

Alternatively, the defendant may choose to risk a default judgment. A civil defendant might wait to contest a judgment until after the entry of default, or until the plaintiff obtains and seeks to register a default judgment, for a number of reasons. The defendant may believe that settlement is possible, may prefer to postpone the expenditure of her time and money until a later date, ${ }^{2}$ or may wish to contest jurisdiction in a forum closer to her assets. Since the plaintiff may move for the court to attach these assets, this wait and challenge approach may allow a defendant to appear in a forum closer to home, where the defendant has a more prominent presence and better access to choice legal counsel than she does in the forum of the issuing court. Federal Rule of Civil Procedure 60(b)(4) allows a defendant to attack a default judgment by subsequently challenging the personal jurisdiction of the court that issued the judgment.

Which party should bear the burden of proof in such a motion? Rule 60 is silent on the issue and the other federal rules provide no explicit answers. However, the controlling burden of proof rule is often critical: in over 90 percent of the reported cases where courts have ruled on Rule 60(b)(4) motions to void a default judgment for lack of personal jurisdiction, the party bearing the burden of proof has lost." The allocation of the burden of proof may drive a case's final disposition.

$\dagger$ B.S. 1996, Northwestern University; J.D. Candidate 2001, The University of Chicago.

1 Under Rule 12(b)(2), a defendant may challenge personal jurisdiction. FRCP 12(b)(2).

2 See, for example, Joseph W. Glannon, Civil Procedure: Examples and Explanations 44 (Aspen 3d ed 1997) (A party has a right to ignore a "harassing" or ineffectual suit for any reason if convinced that the court lacks personal jurisdiction.).

3 Federal Rule of Civil Procedure 60(b)(4) allows the court to relieve the party from a final judgment that is void. FRCP $60(\mathrm{~b})(4)$.

4 See note 165 and accompanying text. 
This question of how the burden of proof should be allocated in Rule 60(b)(4) motions advanced on personal jurisdiction grounds has caused sharp and, to date, unresolved conflict among the lower federal courts. The Supreme Court and most of the federal appellate courts have not squarely addressed this narrow but important question. Further, despite the lack of a clear rule for allocating the burden of proof in Rule 60(b)(4) motions based on personal jurisdiction, scholars have overlooked the issue.

This Comment attempts to fill in that analytical gap. Part I defines the elements of a personal jurisdiction challenge and discusses these challenges and the burden of proof in the context of Rules 12 , 55 , and 60. Part II analyzes the competing approaches courts have employed to allocate the burden of proof for $60(\mathrm{~b})(4)$ motions advanced on personal jurisdiction grounds. Part III argues that courts should adopt a rule placing the burden on the movant but should condition the remedy to mitigate any resulting inequities.

\section{Personal Jurisdiction, Challenges to Personal JURISDICTION, AND THE BURDEN OF PROOF}

\section{A. Personal Jurisdiction}

Personal jurisdiction is a court's power to bind a party with a judgment. ${ }^{6}$ Without personal jurisdiction, a civil judgment, whether default or merits-based, may be devoid of legal authority; valid personal jurisdiction is required for a court to enforce a judgment.' For a court

5 Two annotated treatises have briefly addressed the allocation of the burden of proof for Rule 60 motions or motions to set aside default judgments. See Theresa L. Kruk, Annotation, Who Has Burden of Proof in Proceeding Under Rule 60(b)(4) of Federal Rules of Civil Procedure to Have Default Judgment Set Aside on Ground That it is Void for Lack of Jurisdiction, 102 ALR Fed 811 (1991 \& Supp 2000); Annotation, Burden of Proof Under FR Civ P, Rule 60(b)(4), 47 Am Jur 2d Judgments $\$ 860$ (1995 \& Supp 1999). For a discussion of 60(b)(4) challenges generally, see Milton Roberts, Annotation, Lack of Jurisdiction, or Jurisdictional Error, as Rendering Federal District Court Judgment "Void" For Purposes of Relief under Rule 60(b)(4) of Federal Rules of Civil Procedure, 59 ALR Fed 831 (1982 \& Supp 2000); John Sutham, Note, Brokering $a$ Difficult Marriage: Substantive Defenses Under Rule 60(b)(4) Relief from Default Judgments in Foreign Sovereign Immunities Act Proceedings, 14 Fordham Intl L J 216, 223-26 (1990-91).

6 See Pennoyer $v$ Neff, 95 US 714, 728 (1877) (holding that the validity of a judgment depends upon the proper jurisdiction of the court rendering the judgment). Courts and commentators use the Latin term "in personam jurisdiction" interchangeably with "personal jurisdiction"; for simplicity, this Comment uses only the English variant. See Black's Law Dictionary 791 (West 6th ed 1990).

7 Precision Etchings \& Findings, Inc v LPG Gem, Ltd, 953 F2d 21, 23 (1st Cir 1992) (holding that a default judgment entered by a court lacking personal jurisdiction over the defendant is void); Venable v Haislip, 721 F2d 297, 300 (10th Cir 1983) ("If the underlying judgment is void for lack of personal ... jurisdiction ... the district court must grant relief."); Textile Banking Co v Rentschuler, 657 F2d 844, 850 (7th Cir 1981) (" [I]f the underlying judgment is void because the court lacked personal ... jurisdiction ... the trial judge has no discretion and must grant appropriate Rule 60(b) relief."). See generally Charles Alan Wright, Arthur R. Miller, and Mary Kay 
to have valid personal jurisdiction over a defendant, three elements must be satisfied. First, either a valid statute of the forum state or the state's common law must authorize the exercise of jurisdiction over the defendant. ${ }^{8}$ Second, the due process provisions of the United States Constitution's Fifth and Fourteenth Amendments must permit that grant of jurisdiction.' Third, the defendant must be "properly brought" before the court in the particular action. ${ }^{10}$ Either the defendant's waiver of her personal jurisdiction objection through voluntary appearance in the action ${ }^{11}$ or valid service of process on the defendant "in strict conformance" with the authorizing statute may satisfy this third condition.

\section{B. Personal Jurisdiction Challenges and the Burden of Proof}

A defendant may challenge any of these requisite elements of the issuing court's personal jurisdiction. The defendant may initiate this challenge prior to appeal at one of three stages in the litigation. ${ }^{13}$ For

Kane, 11 Federal Practice and Procedure $§ 2862$ (West 2d ed 1995); James Wm. Moore, 7 Moore’s Federal Practice \I 60.25[2] (Matthew Bender 2d ed 1996).

8 Leab v Streit, 584 F Supp 748, 755 (S D NY 1984) (noting that the court must determine whether the appropriate lawmakers have chosen to grant the power to exercise jurisdiction over the defendant).

$9 \quad$ See Bank Brussels Lambert v Fiddler Gonzalez \& Rodriguez, 171 F3d 779, 784 (2d Cir 1999) (stating that a court must determine whether exercise of jurisdiction over the parties is consistent with the constitutional guarantee of due process); Leab, $584 \mathrm{~F}$ Supp at 755 (noting the court must determine whether the grant of jurisdictional power comports with constitutional limitations upon the exercise of jurisdiction over a person).

$10 \quad$ Leab, 584 F Supp at 755.

11 "Appearance" in this context refers to a general appearance, where the party offers a "simple and unqualified or unrestricted submission to the jurisdiction of the court." Black's Law Dictionary at 97 (cited in note 6). This is in contrast to a special appearance, which is an appearance to challenge the sufficiency of service or the court's jurisdiction. Id.

12 Veeck $v$ Commodity Enterprises, Inc, 487 F2d 423, 426 (9th Cir 1973) (holding that the court lacked personal jurisdiction over the defendant because the plaintiff's service was not in strict conformance with Rule 4). See also Mississippi Publishing Corp v Murphree, 326 US 438, 444-45 (1946) ("S "S]ervice of summons is the procedure by which a court having venue and jurisdiction of the subject matter of the suit asserts jurisdiction over the person of the party served."); In re Brackett, 243 BR 910, 913 (Bankr N D Ga 2000), quoting Hansberry v Lee, 311 US 32, 40 (1940) ("It is a principle of general application in Anglo-American jurisprudence that one is not bound by a judgment in personam in a litigation ... to which he has not been made a party by service of process."); Leab, $584 \mathrm{~F}$ Supp at 760 (invalidating personal jurisdiction because of defective service).

13 The filing of a motion under Rule 60 does not affect the time in which an appeal must be filed. See Browder v Director, Department of Corrections of Illinois, 434 US 257, 263 n 7 (1978). The filing of an appeal, however, will deprive the district court of jurisdiction to decide the Rule 60(b)(4) motion if the court has not already done so. See Crateo, Inc v Intermark, Inc, 536 F2d 862,869 (9th Cir 1976). Nevertheless, "some courts will at least indicate on the record that they would grant the motion if the case were remanded by the Court of Appeals, which may influence the appellate court to remand for the purpose, rather than expend the time and effort required to decide the appeal." Kruk, 102 ALR Fed at 817 (cited in note 5). However, "after the appellate court has decided the issues raised in the appeal, if it elects to do so, the lower court can then 
challenges at each of the three stages, the question arises as to which party bears the burden of proof on the issue of personal jurisdiction.

\section{Challenges, prior to a judgment, under Rule 12: the burden is on the plaintiff.}

First, the defendant may elect to respond to the complaint by filing a Rule 12(b)(2) motion to dismiss for "lack of jurisdiction over the person." Should the defendant choose to file a Rule 12 motion challenging the court's personal jurisdiction, the defendant may concomitantly offer arguments on the substantive merits of a complaint's cause(s) of action..$^{15}$ In this situation, where the defendant does argue personal jurisdiction in the motion to dismiss, the defendant, if the motion is denied, can later pursue on direct appeal both the jurisdictional issue and arguments germane to the merits. ${ }^{16}$ If the defendant files the Rule 12(b)(2) motion, the defendant is precluded from renewing, prior to appeal, the jurisdictional attack in a collateral proceeding such as a post-judgment motion under Rule $60 .^{17}$

Generally, civil plaintiffs bear the burden of proof. ${ }^{18}$ As the parties seeking legal remedies, ${ }^{19}$ plaintiffs assume the burden of proving their right to relief in the substantive cause of action. ${ }^{20}$ Plaintiffs' burden of

again assume jurisdiction and act on the Rule $60(\mathrm{~b})(4)$ motion." Id. Of course, in order to raise the personal jurisdiction objection on appeal, it is "well settled" that the defendant must have previously raised the objection below. See Foremost-McKesson, Inc v Islamic Republic of Iran, 905 F2d 438, 453 (DC Cir 1990).

14 FRCP 12(b)(2).

15 See Practical Concepts, Inc v Republic of Bolivia, 811 F2d 1543, 1547 (DC Cir 1987) (R. Ginsburg) (If defendant pursues the jurisdictional challenge within the suit, the party may also defend on the merits.), citing Baldwin v Iowa State Traveling Men's Association, 283 US 522, 525 (1931). However, if the defendant's motion to dismiss addresses only issues extrinsic to personal jurisdiction, Rule $12(\mathrm{~h})$ provides that the defendant generally waives its personal jurisdiction defense. FRCP 12(h)(1). See also Swaim v Moltan Co, 73 F3d 711, 717 (7th Cir 1996) (stating in dicta that a defendant's failure to argue the issue of personal jurisdiction in a responsive pleading typically amounts to a waiver of personal jurisdiction).

16 Practical Concepts, 811 F2d at 1547.

17 See id at $1545-48,1552$.

18 The term "burden of proof" usually "refers to two different burdens: the burden of production and the burden of persuasion." John J. Cound, et al, Civil Procedure: Cases and Materials 992 (West 7th ed 1997). The burden of production requires only that the party produce sufficient evidence such that a reasonable factfinder could find in its favor; therefore, one can meet the burden of production even if the opposing party refutes all of the evidence produced. Id. If the burden of production is met in a civil action, the case can move forward to the stage of persuasion. Id. In this sense, the party bearing the burden of persuasion bears the risk of nonpersuasion. Fleming James, Jr., Geoffrey C. Hazard, Jr., and John Leubsdorf, Civil Procedure 324 (Little, Brown 4th ed 1992) (Civil jury instructions commonly direct the jury to rule against the party with the burden of persuasion in the event of a tie.).

19 A remedy is "anything a court can do for a litigant who has been wronged or is about to be wronged." Douglas Laycock, Modern American Remedies: Cases and Materials 1 (Little, Brown 2d ed 1994).

20 See Charles C. McCormick, 2 McCormick on Evidence $\$ 337$ at 428 (West 4th ed 1992) 
establishing their right to relief includes the burden of establishing the existence of valid personal jurisdiction. ${ }^{21}$ In Rule 12(b)(2) motions where the defendant challenges the legal sufficiency of the plaintiff's allegations of personal jurisdiction, courts have consistently held that plaintiffs retain this burden. ${ }^{22}$ Thus, in motions to dismiss pursuant to Rule 12(b)(2), plaintiffs, consistent with their overall burden of proving their claim at trial, bear the burden of establishing personal jurisdiction.

2. Challenges to an entry of default under Rule 55: the burden is on the plaintiff.

a) Distinguishing an entry of default from a default judgment. A defendant who declines to file a Rule 12 motion may challenge the court's personal jurisdiction at one of two subsequent stages in litigation: either following the entry of default or following an adverse default judgment. ${ }^{23}$ A default occurs when a defendant "has failed to defend against a claim ... brought by another party," often by failing to appear at trial. ${ }^{24}$ An entry of default, then, is the formal judicial "recognition of the fact that one party is in default." ${ }^{\text {25 }}$ An entry of default is "a non-final order" that is "not appealable."

A default judgment, in contrast, requires the court to ascertain the precise remedy and the "measure of recovery.", In support of a motion for a default judgment, a plaintiff first files an entry of default, and then may present evidence concerning the precise remedy at a hearing if the court so orders. ${ }^{28}$ While defendants generally receive no-

(John William Strong, ed) ("The burdens of pleading and proof ... have been ... assigned to the plaintiff[,] who generally seeks to change the present state of affairs and who therefore naturally should be expected to bear the risk of failure of proof or persuasion.").

21 McNutt v General Motors Acceptance Corp, 298 US 178, 189 (1936) (Because the plaintiff "is seeking relief . . . it follows that he must carry throughout the litigation the burden of showing that he is properly in court.").

22 See Bank Brussels Lambert v Fiddler Gonzalez \& Rodriguez, 171 F3d 779, 784 (2d Cir 1999) ("When responding to a Rule 12(b)(2) motion to dismiss for lack of personal jurisdiction, the plaintiff bears the burden of establishing that the court has jurisdiction over the defendant."); Ballard v Savage, 65 F3d 1495, 1498 (9th Cir 1995) (stating that on a Rule 12(b)(2) motion, plaintiff must "demonstrate facts that if true would support jurisdiction"); Bally Export Corp v Balicar, Ltd, 804 F2d 398, 401 (7th Cir 1986) ("Normally it is well established that the plaintiff must prove jurisdiction exists once it is challenged by the defendant.").

23 See, for example, Enron Oil Corp v Diakuhara, 10 F3d 90, 96-97 (2d Cir 1993) (analyzing the propriety of both the lower court's entry of default and its default judgment).

24 Black's Law Dictionary at 417-18 (cited in note 6).

25 Cound, et al, Civil Procedure at 912-13 (cited in note 18), quoting Wright, Miller, and Kane, 10 Federal Practice and Procedure at $\$ 2692$ (cited in note 7).

26 Enron, $10 \mathrm{F3d}$ at 95 (reviewing the procedural requirements for default judgments).

27 Cound, et al, Civil Procedure at 913 (cited in note 18). See FRCP 55(b). See also Enron, 10 F3d at 95 .

28 See FRCP 55(b). See also Enron, 10 F3d at 95. 
tice of the hearing, a defendant's wait and challenge strategy often means that the hearing is held in the defendant's absence. ${ }^{29}$ Once the plaintiff obtains a default judgment, the plaintiff may register the judgment for collection in any federal judicial district, often the district where the defendant's principal assets are located. ${ }^{30}$ Unlike the entry of default, which is a non-final interlocutory order, the default judgment is a final action and may be appealed."

Following either an entry of default or a subsequent default judgment, the defendant may raise the issue of personal jurisdiction in a collateral proceeding. ${ }^{32}$ For such collateral proceedings, Rules 55 and 60 provide the framework for defendants to challenge the validity of the original issuing court's personal jurisdiction.

Rule 55 distinguishes between the setting aside of "an entry of default" and the setting aside of a "judgment by default." "Under Rule 55 (c), courts may vacate an entry of default for any "good cause shown." In applying the good cause standard, courts enjoy "considerable latitude. ${ }^{, 35}$ As discussed in Part I.B.3, the standard for vacating a default judgment is similarly open-ended.

b) The burden of proof in motions to vacate an entry of default. For defendants' Rule 55 motions to vacate an entry of default - just as for Rule 12 motions to dismiss-plaintiffs bear the burden of proving that the court has personal jurisdiction. The one court that allocated the burden to the defendant was reversed. In General Contracting \&

29 See, for example, Callier v Gray, 167 F3d 977, 978-79 (6th Cir 1999) (Defendant was not present at evidentiary hearing.).

30 See 28 USC \$ 1963 (1994) (providing for the registration of federal judgments in other judicial districts for enforcement); Drexler v Kozloff, 2000 US App LEXIS 6761, *5-6 (10th Cir) (noting the propriety of the plaintiff's registration of a judgment issued by a federal district court in Colorado in a federal district court in the Southern District of New York). The plaintiff may register the judgment in federal court regardless of the court in which the original judgment was issued. See 28 USC $\$ 1963$. Federal courts must also give a foreign state court judgment "the same full faith and credit" as it "would have in the courts of the state from which it came." Drexler, 2000 US App LEXIS 6761 at *8 (citations omitted).

31 See Enron, 10 F3d at 95 (reviewing procedural requirements for default judgments).

32 Insurance Corp of Ireland, Ltd v Compagnie des Bauxites de Guinee, 456 US 694, 706 (1982) (A party may always ignore a judicial proceeding and challenge the default judgment on jurisdictional grounds in a collateral proceeding.). This challenge to the issuing court's jurisdiction may be brought in either the issuing court or the court of registration. See Graciette $v$ Star Guidance, Inc, 66 FRD 424, 426 (S D NY 1975) (noting that a void judgment may be challenged by collateral attack in any court where its validity is an issue).

33 Cound, et al, Civil Procedure at 912 (cited in note 18).

34 FRCP 55(c).

35 Sparton Engineered Products, Inc v Cable Control Technologies, Inc, 1999 US App LEXIS 2283, *9 (6th Cir) (unpublished opinion) ("When a defendant seeks relief from a default that has been entered ... by the clerk upon a plaintiff's request, the district court enjoys considerable latitude under the 'good cause shown' standard of [Rule 55(c)]."). See also Johnson v Dayton Electric Manufacturing Co, 140 F3d 781, 785 (8th Cir 1998) ("Rule 55 issues are committed to the district court's discretion ...."). 
Trading Co $v$ Interpole, Inc, ${ }^{36}$ the First Circuit reviewed a district court's denial of the defendant's motion to set aside an entry of default. ${ }^{37}$ In denying the defendant's motion, the district court had placed the burden of proof on the defendant to prove that the court lacked jurisdiction. ${ }^{38}$ Reversing, the First Circuit emphasized the "fundamental relationship of the jurisdictional inquiry to the judicial task, ${ }^{, 39}$ and held that "the burden of proving jurisdiction rests with the party asserting the affirmative of the proposition." ${ }^{40}$ The court concluded that the district court "erred in never placing the devoir of persuasion on [the plaintiff]." "Thus, for motions to set aside an entry of default, "the burden of demonstrating the existence of personal jurisdiction ... remains with the plaintiff after the plaintiff has obtained a default." ${ }^{42}$ In ruling on the defendant's Rule 55(c) motion to vacate the entry of default, a court should resolve "[a]ny doubts ... in favor of setting aside a default so that a determination may be made on the merits of the case." ${ }^{43}$ Numerous other courts have similarly placed the burden on the plaintiff in Rule 55(c) motions to vacate an entry of default due to lack of personal jurisdiction. ${ }^{44}$

\section{Challenges to a default judgment under Rule 60: whose burden?}

For motions to vacate a default judgment, as opposed to an entry of default, Rule 55(c) permits a court to grant the motion "in accordance with Rule 60(b).," Rule 60(b), in turn, provides that "[o]n motion and upon such terms as are just, the court may relieve a party or a

36899 F2d 109 (1st Cir 1990).

37 Id at 111.

38 Id at $115-16$.

39 Id at 116.

40 Id at 115, quoting Donatelli v National Hockey League, 893 F2d 459, 468 (1st Cir 1990).

41 General Contracting, $899 \mathrm{~F} 2 \mathrm{~d}$ at 115-16 (remanding the cause of action to the lower court for the issue of personal jurisdiction "to be aired more fully").

42 Southmark San Juan, Inc v Abbas Atash-Sobh, 1994 WL 1031279, *2 (Va Cir Ct) (following General Contracting in placing the burden on the plaintiff in a motion to vacate an entry of default).

43 Lichtenstein $v$ Jewelart, Inc, 95 FRD 511, 513 (E D NY 1982).

44 See, for example, Enron, $10 \mathrm{~F} 3 \mathrm{~d}$ at 96,98 . In reversing the district court's denial of the defendant's Rule 55(c) motion to vacate an entry of default, the court stated "because defaults are generally disfavored and are reserved for rare occasions, when doubt exists as to whether a default should be granted or vacated, the doubt should be resolved in favor of the defaulting party .... [W] hat is clear is that under the case law all doubts must be resolved in favor of trial on the merits." Id. See also Barnes v Printron, Inc, 1999 US Dist LEXIS 7726, *6 (S D NY) ("Because the record does not permit the Court to determine ... whether service upon that person would satisfy the requirements of Fed.R.Civ.P. 4, the Court must conclude that the default [judgment] is void."); Lichtenstein, 95 FRD at $513 \mathrm{n} 3$ (granting Rule 55(c) motion because it was "[r]esolving the doubt in favor of the defendant").

45 FRCP 55(c). 
party's legal representative from a final judgment, order, or proceeding for the following reason[ ] ... the judgment is void."

In the Rule 60(b)(4) context, the term "void" encompasses any "default judgment entered by a court which lacks jurisdiction over the person of the defendant." "This definition is well-settled: it is "beyond peradventure that a void judgment, such as one entered by a court which lacks personal jurisdiction . . . is a nullity." ${ }^{48}$ Courts are barred from enforcing these void judgments; if a court analyzing a $60(\mathrm{~b})(4)$ motion to vacate finds that the issuing court lacked personal jurisdiction, the court lacks any discretion and must refuse to enforce the judgment. ${ }^{49}$ Courts are required to grant relief from default judgment upon a showing of lack of jurisdiction in 60(b)(4) motions because "[e]ither a judgment is void or it is valid.", Therefore, defendants subject to a void judgment can rely on Rule 60 to prevent the enforcement of the adverse default judgment.

An entry of default and a default judgment, while distinct, are closely related steps in a plaintiff's pursuit of her cause of action. The language in Rules 55 and 60, authorizing relief from entry of default and default judgment, is similar. Under Rule 55(c), as stated, a court may set aside an entry of default for "any good cause shown." Rule 60(b) also employs a rather open-ended grant of judicial discretion, providing that the reviewing court may relieve a party from a final judgment "upon such terms as are just," including when "the judgment is void." Additionally, the two types of attacks occur at functionally equivalent stages in the litigation process, both after the entry of default, but before the defendant has responded to the plaintiff's complaint.

46 FRCP 60(b).

47 Precision Etchings \& Findings, Inc v LPG Gem, Ltd, 953 F2d 21, 23 (1st Cir 1992).

48 General Contracting, 899 F2d at 114.

49 See Bally Export Corp v Balicar, Ltd, 804 F2d 398, 400 (7th Cir 1986) (holding that "when the rule $60(\mathrm{~b})(4)$ motion alleges that that 'the underlying judgment is void because the court lacked personal or subject matter jurisdiction,' once the court decides that the allegations are correct, 'the trial judge has no discretion and must grant appropriate Rule 60(b) relief'"); Gulf Coast Fans, Inc v Midwest Electronics Importers, Inc, 740 F2d 1499, 1511-12 (11th Cir 1984) (holding that the district court's refusal to set aside a default judgment constituted an abuse of discretion where the presence of personal jurisdiction was not established); Venable $v$ Haislip, $721 \mathrm{~F} 2 \mathrm{~d} 297,300$ (10th Cir 1983) (stating that if a judgment is void for lack of personal jurisdiction, the court must grant relief). See also Wright, Miller, and Kane, 11 Federal Practice and Procedure at $\$ 2862$ (cited in note 7) ("There is no question of discretion on the part of the court when a motion is under Rule 60(b)(4).") (collecting cases).

50 Thos. P. Gonzalez Corp v Consejo Nacional De Produccion De Costa Rica, 614 F2d 1247, 1256 (9th Cir 1980) (holding there was a duty to vacate since the defendant's Rule 60(b)(4) motion identified valid grounds for setting aside the judgment).

51 FRCP 55(c).

52 FRCP 60(b). 
Thus, a court reviewing a Rule 60(b)(4) motion challenging personal jurisdiction must find the default judgment void in order to vacate the judgment. It is far from clear, however, which party bears the burden of proof on the issue of personal jurisdiction. As the following discussion demonstrates, unlike the standard for personal jurisdiction challenges advanced under Rules 12 and 55, courts have failed to develop a uniform rule in Rule 60(b)(4) motions for allocating the burden of proof on the issue of personal jurisdiction.

\section{Allocating the Burden in Motions to Vacate a Default JUDGMENT AS VOID FOR LACK OF PERSONAL JURISDICTION}

This Comment makes two principal claims, one descriptive and one normative. In Part III, this Comment develops a normative claim as to which rule should control in allocating the burden of proof in Rule 60(b)(4) motions to vacate a default judgment for lack of personal jurisdiction. This Part focuses on the descriptive claim that courts are divided in their approach to allocating the burden of proof. This division is even more pronounced than recent courts have recognized. Courts have employed four competing approaches to allocating the burden in Rule 60(b)(4) motions, two major and two "outlier" approaches.

\section{A. Rockwell: The View That the Burden Remains with the Plaintiff}

A number of district courts in the Second, ${ }^{53}$ Third, ${ }^{54}$ Fifth, ${ }^{55}$ and Sixth $^{56}$ Circuits have held that the burden of proof remains with the plaintiff in a motion to vacate a default judgment as void for lack of personal jurisdiction. In Rockwell International Corp v KND Corp, the court reviewed the defendant's 60(b)(4) motion and held that the plaintiff bore the burden to establish personal jurisdiction for two rea-

53 See Ocala Waste Disposal Associates v GGC, Inc, 1993 US Dist LEXIS 5578, *5 (S D NY) (explaining that "[a]dequacy of service is an element of personal jurisdiction, and the burden of proof as to its adequacy is on the party asserting that jurisdiction exists"); Triad Energy Corp v McNell, 110 FRD 382, 385 (S D NY 1986) (holding that when "personal jurisdiction is contested under Rule $60(\mathrm{~b})(4)$, the burden of proof is properly placed on the party asserting that jurisdiction existed"); Leab v Streit, 584 F Supp 748, 760 (S D NY 1984) (same).

54 See Packard Press Corp v Com Vu Corp, 584 F Supp 73, 75-76 (E D Pa 1984) ("The Court has a continuing duty to ensure that such jurisdiction exists before advancing to the merits.... When the court's in personam jurisdiction is challenged by the defendant, the plaintiff must prove that the non-resident defendant's activities in the forum state are sufficient to bring it within the reach of this court's jurisdiction."); DiCesare-Engler Productions, Inc v Mainman $L t d, 421$ F Supp 116 (W D Pa 1976).

55 See Rockwell International Corp v KND Corp, 83 FRD 556 (N D Tex 1979).

56 Sterling Industrial Corp v Telephone, Inc, 484 F Supp 1294, 1296 (W D Mich 1980) (holding that "[w]hen a defendant challenges personal jurisdiction, the plaintiff has the burden of proving by a preponderance of the evidence that the court has jurisdiction over the defendant").

5783 FRD 556 (N D Tex 1979). 
sons. ${ }^{58}$ First, the court stated, "it is difficult to understand how such a burden [on the defendant] would work.". Second, reasoned the court, "it is the plaintiff that typically offers events or circumstances that it characterizes as meeting state statutory and federal due process standards."

Similarly, in DiCesare-Engler Productions, Inc v Mainman Ltd, ${ }^{61}$ the plaintiff filed suit in a state court against several defendants, including the entertainer David Bowie. ${ }^{62}$ The plaintiff obtained a default judgment from the state court against Bowie and registered that judgment in a federal district court. ${ }^{63}$ Bowie moved to vacate the default judgment, arguing that the service of process in the original state court action was improper and that the subsequent judgment was therefore void for lack of personal jurisdiction. ${ }^{64}$ In granting the motion to vacate, the court held that the plaintiff bore the burden of proving that it had satisfied the service of process component of personal jurisdiction, required by the relevant long-arm statute, by mailing notice of the default judgment to Bowie's last known address. ${ }^{6.5}$ Because the plaintiff failed to carry its burden, the state court never obtained proper jurisdiction over Bowie and the default judgment was void and vacated by the district court for this reason. ${ }^{66}$

A number of subsequent courts have likewise placed the burden of proof on the nonmovant plaintiff in Rule 60(b)(4) motions to vacate a default judgment for lack of personal jurisdiction. ${ }^{67}$ Aside from iterating the proposition that the burden of proof is on the plaintiff and providing citations, these courts have offered no further rationale for adopting the rule beyond the terse justifications articulated in Rockwell and DiCesare. Thus, the view that the burden remains with the plaintiff, while fairly prevalent among lower federal courts, is largely undertheorized.

\section{B. Rohm: The View That the Burden Shifts to the Defendant}

In contrast to the Rockwell line of authority, the Seventh Circuit Court of Appeals ${ }^{68}$ and certain lower courts in the Second ${ }^{69}$ and Elev-

58 See id at $559 \mathrm{n} 1$.

59 Id. The court further contended, with no further elaboration, that the characteristics of Rule 60(b)(4) cases do not favor allocating the burden to the defendant. Id.

60 Id.

61 421 F Supp 116 (W D Pa 1976).

62 Id at 118.

63 Id at 119.

64 Id.

65 Id at 120-21.

66 Id at 121.

67 See cases cited in notes 53-56.

68 See Bally Export Corp v Balicar, Ltd, 804 F2d 398, 401 (7th Cir 1986), discussed in text 
enth $^{70}$ Circuits have held that defendants with notice of a lawsuit who challenge a default judgment on jurisdictional grounds must bear the burden of proof. Notice in this context appears to refer to evidence of the defendant's awareness or knowledge of the suit, rather than a strict definition linked to statutorily established service of process requirements. $^{\text {" }}$

Rohm \& Haas Co $v$ Aries $^{n}$ was the first judicial opinion to depart openly from the Rockwell rule. In Rohm, the district court analyzed the defendant-purchaser's Rule 60(b)(4) motion to vacate a twentyyear-old monetary default judgment registered by the plaintiffsupplier as void for lack of personal jurisdiction. ${ }^{73}$ In addressing the burden of proof, the court, citing no authority, criticized and then rejected the Rockwell approach. ${ }^{74}$ The court stated that the reasoning underlying those courts' allocation of the burden to the plaintiff "fails to consider that a defendant who was on notice of the original proceedings had an opportunity, at that time, to oppose jurisdiction by a Rule 12 motion." unlike for Rule 60 motions, the rule requiring plaintiffs to bear the burden of proof avoids prejudice to the plaintiff because all evidence needed to prove jurisdiction is readily available. ${ }^{76}$ For Rule $60(\mathrm{~b})$ mo-

accompanying notes 80-83. District courts in the Seventh Circuit have consistently followed this rule. See, for example, Invest L'Inc v ITS International, Inc, 1998 US Dist LEXIS 17915, *6-7 (N D III) (allocating the burden of proof on personal jurisdiction to defendants bringing the 60(b)(4) collateral attack); Carr v Pouilloux, SA, 947 F Supp 393, 395 (C D Ill 1996) (same).

69 See Miller $v$ Jones, 779 F Supp 207, 210 (D Conn 1991) (holding that the burden of demonstrating lack of personal jurisdiction shifts to the defendant who was properly served but failed to appear in the original proceeding); International Housing Ltd v Rafidain Bank Iraq, 712 F Supp 1112,1114, 1119-20 (S D NY 1989) (vacating a default judgment against a foreign sovereign defendant due to lack of minimum contacts, but placing jurisdictional burden on the defendant), revd on other grounds, $893 \mathrm{~F} 2 \mathrm{~d} 8$ (2d Cir 1989). Thus, not only is there a circuit split regarding the burden of proof on the issue of personal jurisdiction in $60(\mathrm{~b})(4)$ motions, but also there is a split within the Second Circuit. Compare Miller, 779 F Supp at 210, and International Housing, 712 F Supp at 1114, with Ocala Waste Disposal Associates v GGC, Inc, 1993 US Dist LEXIS 5578, *5 (S D NY) (following the Rockwell rule of placing the burden on the plaintiff); Triad Energy Corp v McNell, 110 FRD 382, 385 (S D NY 1986) (same); Leab v Streit, 584 F Supp 748, 760 (S D NY 1984) (same).

70 In re Brackett, 243 BR 910, 914 (Bankr N D Ga 2000) (stating that the burden lies with the defaulting party raising the challenge and defendants' mere assertion that service was not received is insufficient).

71 See China Mariners' Assurance Corp v MTWM Vacy Ash, 1999 US Dist LEXIS 2674, *22 (S D NY) (distinguishing defendant's receipt of notice from defendant's receipt of service of process pursuant to FRCP 4(h)(1) and NY CPLR $\$ 311.1$ (McKinney 2000) in conformity with the full requirements of the statute in the context of a Rule $60(\mathrm{~b})(4)$ motion advanced on personal jurisdiction grounds).

72103 FRD 541 (S D NY 1984).

73 Id at 542-43.

74 Id at 544 .

75 Id.

76 Id. 
tions, however, the court reasoned, "Should the burden of proof be lodged with the plaintiff, severe prejudice can result when evidence needed to prove jurisdiction is no longer available due to the passage of time." Therefore, the court concluded, it is "not unfair" to place the burden on a defendant who was on notice at the time of the original proceeding if the defendant chooses to wait until after the entry of an adverse default judgment to attack the court's personal jurisdiction. Allocating the burden of proof to the defendant, the court found that the defendant had failed to meet his burden and denied the motion."

The Seventh Circuit is the only circuit court of appeals to adopt the Rohm court's approach. ${ }^{80}$ In Bally Export Corp v Balicar, Ltd, ${ }^{81}$ the Seventh Circuit adopted the Rohm court's reasoning and rejected the Rockwell rule:

We believe that the approach taken by the court in Rohm \& Haas is the better one. If the defendant, after receiving notice, chooses to let the case go to a default judgment, the defendant must then shoulder the burden of proof when the defendant decides to contest jurisdiction in a post-judgment rule $60(\mathrm{~b})(4)$ motion.

The court held that the defendants had not met their burden and affirmed denial of the motion. ${ }^{83}$

A number of district courts ${ }^{84}$ have expressly followed Rohm and Bally in rejecting the Rockwell rule. ${ }^{85}$ A recent survey observed that

77 Id (noting that the original default judgment at issue was nearly twenty years old).

78 Id. Significantly, the Rohm court did not qualify its holding by limiting its burden on the defendant rule to situations where extensive time elapsed between the default judgment and the subsequent motion to vacate, as was the case in Rohm itself. However, the court did use the passage of time as one factor it considered in allocating the burden to the defendant. Id.

79 Id at 545 . While the Rohm court states that if the plaintiff had shouldered the burden, the outcome would have been the same, the court's treatment of the notice issue would have likely been affected. See id at $545 \mathrm{n} 2$.

80 Remarkably, the Seventh Circuit is also the only circuit court of appeals to delineate explicitly a rule for allocating the burden of proof for $60(\mathrm{~b})(4)$ motions based on personal jurisdiction. See, for example, Drexler v Kozloff, 2000 US App LEXIS 6761, *13 n 1 (10th Cir) ("[W]e do not here decide the question of who bears the burden of establishing whether in personam jurisdiction existed over a defendant in a proceeding brought pursuant to Rule 60(b)(4) to set aside a default judgment on the ground that it is void for lack of such jurisdiction.").

81804 F2d 398 ( 7 th Cir 1986).

82 Id at 401 . The scope of disagreement between the Rohm and Rockwell approaches is limited to situations where the court has evidence that the defendant knew of the action at the time of the original default judgment. Where the defendant had no such notice, as even the Seventh Circuit in Bally acknowledged, the burden indisputably remains with the plaintiff. See id (noting that by shifting the burden to the defendant, the court "presumes the defendant was on notice at the time of the original proceeding"), quoting Rohm, 103 FRD at 544.

83 Bally, $804 \mathrm{~F} 2 \mathrm{~d}$ at 403 (holding that the defendants conducted sufficient business in Illinois to be captured under the state's long-arm statute).

84 See the cases cited in notes 68-70.

85 See, for example, Brackett, 243 BR at 914 (holding that the burden lies with the default- 
"the general trend throughout the Circuits, and in the Second Circuit, is toward imposing the burden of proof on the party moving to vacate a default judgment under Rule 60(b)(4).,"86

Only one court, however, has added any further rationale for the rule placing the burden of proof on the movant-defendant to establish a lack of personal jurisdiction. In Miller $v$ Jones, ${ }^{87}$ the court denied a motion to vacate and addressed the split between the Rockwell and Rohm lines of authority. ${ }^{88}$ Echoing the court in Rohm, the Miller court cited the "fear of prejudice against a plaintiff who, owing to delay, might in subsequent collateral proceedings no longer have evidence of personal jurisdiction that existed at the time of the underlying suit." ${ }^{89}$ However, the Miller court stated three additional policy interests that were advanced by the Rohm rule: (1) "the concerns of comity among the district courts of the United States"; (2) "the interest in resolving disputes in a single judicial proceeding"; and (3) "the interest of the plaintiff in the choice of forum." Accordingly, the court adopted the Rohm rule and found that the defendants had failed to meet their burden of proof on the issue of personal jurisdiction. ${ }^{91}$

\section{The Two Outlier Approaches}

Some courts have failed to adopt either of these two rules, taking one of two alternative standard-like approaches.

1. The totality of the circumstances approach.

Certain "outlier" courts base their allocation of the burden on the specific "circumstances of [the] case.". In Donnely $v$ Copeland Intra Lenses, Inc, a plaintiff registered a default judgment in a district court of another state, and subsequently brought an enforcement action against the defendant in the court of registration. ${ }^{94}$ The court of registration granted the defendant's Rule $60(\mathrm{~b})(4)$ motion to vacate. ${ }^{95}$ In addressing the burden of proof issue, the court emphasized the plaintiff's relative advantage between the parties in access to information, and concluded:

ing party challenging judgment on service of process grounds).

86 Kruk, Annotation, 102 ALR Fed at 818 (cited in note 5).

87779 F Supp 207 (D Conn 1991).

88 Id at $210-11$.

89 Id.

90 Id at 210.

91 Id at 211-12 ("In light of [defendant's] burden of proof and the scant record before me, for jurisdictional purposes the court must assume the existence of ... personal jurisdiction.").

92 Donnely v Copeland Intra Lenses, Inc, 87 FRD 80, 85 (E D NY 1980).

9387 FRD 80 (E D NY 1980).

94 Id at 82.

95 Id at 86 . 
Although the burden of proof in a Rule 60(b) motion is typically on the movant, it is manifest that in the circumstances of this case the burden is properly on [the plaintiff] to establish ... that [the issuing court] had in personam jurisdiction over the ... defendants.

The court's approach to allocating the burden in China Mariners' Assurance Corp v MTWM Vacy Ash ${ }^{97}$ was similarly focused on the specific facts of the case before the court. ${ }^{98}$ The court analyzed the defendant's 60(b)(4) motion to vacate as void for lack of personal jurisdiction due to plaintiff's alleged failure properly to serve process. ${ }^{99}$ The court initially stated that since the defendant had notice of the original suit, the defendant bore the burden of proof on the personal jurisdiction issue. ${ }^{100}$ The court then applied a burden of proof seemingly at odds with the Rohm-type burden it had just expressly adopted, stating that "the highly controverted story behind service in this case" directed the court to void the judgment. ${ }^{101}$ Because of a stated policy preference in favor of resolving disputes on the merits, "where the parties' accounts of the attempted service differ but both are inherently plausible, and there is nothing in the record upon which to judge the veracity of either version, a court should credit the version of the party seeking to vacate the default." ${ }^{, 102}$ Having switched the allocation of the burden from the defendant to the plaintiff, the court held that the plaintiff had not carried its burden and that the default judgment was void. ${ }^{103}$

2. The court address approach.

As noted, Rule 12 provides that a defendant waives her personal jurisdiction objections unless she raises the issue in a timely responsive pleading. ${ }^{104}$ However, the right to challenge a court's personal jurisdiction is not waived when a defendant defaults. ${ }^{105}$ When a

96 Id at 85 (first emphasis added).

971999 US Dist LEXIS 2674 (S D NY).

98 Id at $* 21$.

99 Id at *7-21.

100 Id at * 10 n 7 ("Defendant bears the burden of proof of establishing its claims for setting aside the default judgment, and must therefore show that service was not properly effected."), citing, inter alia, Rohm, 103 FRD at 544.

101 China Mariners', 1999 US Dist LEXIS 2674 at *21.

102 Id, quoting American Institute of Certified Public Accountants v Affinity Card, Inc, $8 \mathrm{~F}$ Supp 2d 372, 377 (S D NY 1998).

103 China Mariners', 1999 US Dist LEXIS 2674 at *21-27. However, the court questioned the defendant's account and refused to vacate the judgment, instead directing the plaintiff to reserve the defendant.

104 FRCP 12(h)(1); In re Tuli, 172 F3d 707, 712 (9th Cir 1999).

105 See Popper v Podhragy, 48 F Supp 2d 268, 272 (S D NY 1998), citing Williams v Life Savings and Loan, 802 F2d 1200, 1203 (10th Cir 1986). 
plaintiff seeks a default judgment against a defendant who has declined to plead or otherwise defend, the district court has "an affirmative duty" to review its jurisdiction over the parties. ${ }^{106}$

Should the court conclude that it lacks personal jurisdiction, the court may, sua sponte, dismiss the complaint for lack of personal jurisdiction. ${ }^{10}$ This rule is a narrow exception to the general rule that courts may not dismiss an action sua sponte for lack of personal jurisdiction. ${ }^{108}$ The (healthy) premise underlying this exception is one of finite judicial reach. The contours of personal jurisdiction limits are bounded by a court's legitimate power to bind a party with its judgment: "In reviewing its personal jurisdiction, the court ... exercises its responsibility to determine that it has the power to enforce the default judgment."

Thus, where the plaintiff moves for the entry of a default judgment, the court has the opportunity and duty to review the basis for its jurisdiction over the parties. However, courts may, for lack of a welldeveloped record or for other reasons, postpone their initial review of the validity of personal jurisdiction until after the issuance of the default. ${ }^{110}$ At least one court employing such an approach has based its allocation of the burden on whether the issuing court appears to have reviewed the personal jurisdiction question in rendering the default judgment. In Popper v Podhragy, the defendants failed to answer the complaint, and the plaintiffs obtained a default judgment. The defendant then moved in the issuing court to vacate the judgment under Rule 60(b)(4). ${ }^{112}$ Addressing the burden issue, the presiding judge stated, "[T]he Court notified the plaintiff that it had failed to review the question of personal jurisdiction when it entered the default judgment." personal jurisdiction over defendant." court address approach appears to have been an attempt to avoid having to make an explicit choice between the Rockwell rule

106 Garberg \& Associates, Inc v Pack-Tech International Corp, 115 F3d 767, 771-72 (10th Cir 1997), quoting Williams, 802 F2d at 1202-03.

107 See Tuli, 172 F3d at 712 (holding that a lower court properly raised the issue of personal jurisdiction sua sponte); Garberg, 115 F3d at 771-72 ("[T]he district court has an affirmative duty to look into its jurisdiction both over the subject matter and the parties.").

108 See Pilgrim Badge \& Label Corp v Barrios, 857 F2d 1, 3-4 (1st Cir 1988) (holding that a "district court may not sua sponte dismiss for lack of personal jurisdiction except when a default judgment is to be entered"), citing Williams, 802 F2d at 1203.

109 Garberg, 115 F3d at 772 (emphasis omitted), quoting Williams, 802 F2d at 1202-03. 111-15.

110 See, for example, Popper, 48 F Supp $2 \mathrm{~d}$ at 272 , discussed in text accompanying notes

11148 F Supp 2d 268 (S D NY 1998).

112 Id.

113 Id at 271.

114 Id at 272. 
and the Rohm rule. After recognizing that "there is a conflict in the case law as to which party bears the burden of establishing personal jurisdiction in a Rule 60(b)(4) challenge," the court spent two paragraphs in a footnote reviewing the Rohm and Rockwell decisions and their progeny. ${ }^{115}$ However, the court concluded, "that issue was previously resolved" since the court did not "review the question of personal jurisdiction when it entered the default judgment." ${ }^{, 16}$ Thus, some courts use a more particularized approach, by reviewing either the specific aspects of the parties' characteristics or conduct, or by reviewing the scope of the original default judgment hearing. These courts base their allocation of the burden on the individual circumstances of the dispute, rather than on a predetermined rule.

In sum, courts' approaches to allocating the burden have evidenced enormous variance, even more than recent courts have recognized. ${ }^{117}$ Courts grappling with the issue of how to allocate the burden of proof in Rule 60(b)(4) motions to void a default judgment for want of jurisdiction have employed four different approaches to allocating the burden: two major approaches, and two "outlier" approaches.

\section{Courts Should Place THE BuRden ON THE MOVANT BUT SHOULD USE THE REMEDY TO Mitigate ANy Resulting PREJUdice}

Part II showed the tremendous dissensus in the lower federal courts concerning allocation of the burden of proof in Rule 60(b)(4) motions advanced on personal jurisdiction grounds. Adoption of a single consistent approach would clarify the rule and resolve the circuit split.

This Comment's second principal claim is normative: Courts should adopt a firm but balanced rule. Courts should follow Rockwell and DiCesare by requiring that plaintiffs in Rule 60(b)(4) motions bear the burden of proving that the court issuing the default judgment had proper personal jurisdiction. In addition, courts should condition the remedy ${ }^{118}$ to mitigate any resulting inequities.

115 Id at 271 \& n 5.

116 Id at 271.

117 Several courts have recognized the division in authority. See Drexler $v$ Kozloff, 2000 US App LEXIS 6761, *13 n 1 (10th Cir) (noting that "the question of who bears the burden of establishing whether in personam jurisdiction existed over a defendant in a proceeding brought pursuant to rule 60(b)(4)" has engendered a "split in circuits"); Popper, 48 F Supp 2d at 271 (noting that "there is a conflict in the case law as to which party bears the burden of establishing personal jurisdiction in a Rule 60(b)(4) challenge"). However, these courts have recognized only the two main lines of authority: the Rockwell rule discussed in Part II.A and the Rohm rule discussed in Part II.B.

118 See note 19. 


\section{A. A Bright Line Rule Would Allocate the Burden of Proof Consistently}

Courts should develop a bright line rule for allocating the burden of proof in Rule 60(b)(4) motions. A clear rule is desirable because it gives all interested parties notice and because it is more efficient to administer.

\section{Notice.}

A fixed rule clearly allocating the burden provides ex ante notice of how the burden operates. Notice promotes predictability ${ }^{119}$ and informs interested parties of which rule controls. Establishing a clear burden allocation rule would aid both categories of future litigants: plaintiffs would know how much evidence of personal jurisdiction they need to introduce in the record or need to retain, and defendants would be better able to decide whether or not to challenge personal jurisdiction in a Rule 12(b)(2) motion. Establishing a clear rule would also benefit federal courts faced with Rule 60(b)(4) personal jurisdiction challenges, and state courts seeking guidance in their interpretation of state law analogues to Rule 60 .

The court address test suggested by Popper $^{121}$ would tell courts which burden rule should obtain if the issuing court addressed personal jurisdiction. However, by taking no position as to the appropriate default position, that is, by not choosing between the Rohm and Rockwell rules, it provides no guidance for courts where the first jurisdictional review takes place in the court of registration upon the defendant's 60 (b)(4) challenge.

The totality of the circumstances approach, by leaving the allocation to the factual details of each case, makes the situation murky at best, and at worst drives any judicial preferences underground. ${ }^{123} \mathrm{~A}$

119 See Karen M. Gebbia-Panetti, Statutory Interpretation, Democratic Legitimacy and Legal System Values, 21 Seton Hall Leg J 233, 244-46 (1997) (recognizing predictability as a core value of a well-ordered legal system).

120 See Matthies v Railroad Retirement Board, 341 F2d 243, 248 (8th Cir 1965) (noting that $\S 60-260$ of the Kansas Code of Civil Procedure is identical to Federal Rule 60); Estate of Page v Litzenburg, 865 P2d 128, 137 (Ariz App 1993) (recognizing that Arizona courts give great weight to federal courts' interpretations of Rule 60 in interpreting identical text of Arizona Rule of Civil Procedure 60). See also Roberts, Annotation, 59 ALR Fed at 837-38 (cited in note 5) ("[S]ome state courts have expressly adopted the Federal Rules of Civil Procedure, and ... there are state court decisions ... interpreting and applying the state equivalent of [Rule 60(b)(4)].”).

121 See text accompanying notes 111-16; Part II.C.2.

122 Popper, 48 F Supp 2d at 271 (noting two default rules, but failing to endorse either).

123 See, for example, Donnely, 87 FRD at 85 . While the court's totality of the circumstances approach in Donnely was prompted by underlying considerations of fairness, it could also be understood as a court's fundamental distaste for third-party proceedings in the courts of other states. 
party will not know if its case involves "controverted" facts related to personal jurisdiction that will shift the de facto burden to the plaintiff. $^{124}$ By providing courts such enormous discretion to fashion a rule for allocating the burden in a given case, the totality of the circumstances approach amounts to little more than having no rule at all. ${ }^{125}$

\section{Efficiency.}

Adopting a single bright line rule would be efficient. ${ }^{126} \mathrm{~A}$ clear, fixed rule for allocating the burden would minimize administrative costs. By adopting such a rule, courts would promote "uniformity in the federal courts," which is "[o]ne of the shaping purposes of the Federal Rules." ${ }^{127}$ Moreover, reducing the variance in different courts' allocation of the burden would help eliminate the judges' use of "belt and suspenders" opinions that unnecessarily expend judicial resources by employing one burden of proof but then, due to a lack of clarity as to the controlling rule, analyzing the personal jurisdiction issue under a second, competing burden rule. ${ }^{128}$

In contrast stand the two outlier approaches: the totality of the circumstances approach and the court address approach. Because the totality of the circumstances approach ${ }^{129}$ requires courts to analyze the underlying equities of possible prejudice due to the passage of time or the parties' relative advantages of access to relevant jurisdictional information, ${ }^{130}$ the costs of administering such a standard are significant. Under the proposed rule, there would be certain administrative costs associated with analyzing prejudice. Net administrative costs, however, should decrease, because although the court's adoption of a firm rule for allocating the burden will eliminate virtually all costs at that stage, a court need only analyze the prejudice issue when the parties raise

124 See China Mariners', 1999 US Dist LEXIS 2674 at *21.

125 There is, of course, a heated debate among scholars about the merits of rules versus standards. See Louis Kaplow, Rules Versus Standards: An Economic Analysis, 42 Duke L J 557 (1992); Kathleen M. Sullivan, Foreword: The Justices of Rules and Standards, 106 Harv L Rev 22 (1992); Antonin Scalia, The Rule of Law as a Law of Rules, 56 U Chi L Rev 1175 (1989); Duncan Kennedy, Form and Substance in Private Law Adjudication, 89 Harv L Rev 1685, 1685-1713 (1976).

126 See Hiroshi Motumura, Judicial Review in Immigration Cases After AADC: Lessons From Civil Procedure, 14 Georgetown Immig L J 385, 392 (2000) (noting the prominent role of efficiency concerns in judicial interpretation of civil procedure issues). See also A.C. Pritchard, Note, Government Promises and Due Process: An Economic Analysis of the "New Property," 77 Va L Rev 1053, 1073 (1991) (reviewing, in various legal contexts, the ways in which clear rules can lower the cost of administering rules).

127 Hanna $v$ Plumer, 380 US 460, 472-73 (1965).

128 See, for example, Rohm, 103 FRD at $545 \mathrm{n} 2$ ("Even if the burden were placed with petitioner, the result would have been the same.").

129 See Part II.C.1.

130 See Donnely, 87 FRD at 85 (analyzing the latter). 
the issue or where potential prejudice is obvious. Even assuming away costs, the benefits of the totality of the circumstances approach are tenuous.

The court address approach ${ }^{131}$ may also suffer from inefficiency. Under this approach, a court must memorialize the scope of its review in the default proceeding. In any subsequent action to enforce the judgment, especially those where the court of registration differs from the issuing court, there will be administrative costs associated with reviewing the record to determine the extent to which the issuing court reviewed the personal jurisdiction.

The outlier approaches also create significant line-drawing problems. How much time must pass for the likelihood of prejudice due to loss of evidence to trigger the shifting of the burden? How much access must the nonmovant have to jurisdiction-establishing facts? Even with extensive inquiry and analysis, it may be hard to know. Similarly, the court address approach may also create line-drawing problems: how much review constitutes "review"? While courts can engage in line-drawing - they do in many areas of the law ${ }^{132}$ - the decision costs may be more significant where such an exercise is mandated. Such proceedings should not consume courts' finite resources. ${ }^{133}$ Courts should reject both outlier approaches and instead adopt a more efficient bright line rule.

\section{B. The Best Rule Allocates the Burden to the Plaintiff and Uses the Remedy to Account for Any Unfairness}

Part III.A argued that courts should adopt a bright line rule. This conclusion, however, does not resolve which rule is most desirable. Courts should follow the Rockwell rule and place the burden of proving personal jurisdiction on the plaintiff as the party that seeks to establish the existence of personal jurisdiction. However, while adopting the Rockwell rule, courts, in crafting a remedy, should seize on the language of Rule 60 to account for possible harm to plaintiffs. Rule 60(b) provides that a judgment may be vacated "upon such terms as are just." ${ }^{134}$

131 See Part II.C.2.

132 See, for example, Brandon Garrett, Note, Standing While Black: Distinguishing Lyons in Racial Profiling Cases, 100 Colum L Rev 1815, 1822 (2000) (discussing courts' line-drawing approaches in racial profiling cases); Inna Reznik, Note, The Distinction Between Legislative and Adjudicate Decisions in Dolan v. City of Tigard, 75 NYU L Rev 242, 262 n 103 (2000) (zoning); Glenn J. Moramarco, Beyond "Magic Words": Using Self-Disclosure to Regulate Electioneering, 49 Cath U L Rev 107, 129-30 (1999) (discussing the First Amendment).

133 See, for example, Chase International, Inc $v$ Link and Pan of Texas, Inc, 1995 US Dist LEXIS 11981, *2 (N D Ill) (lamenting federal courts' "[o]vercrowded dockets").

134 FRCP 60(b). 
The proposal that courts should vary the terms of the remedy based on the specifics of the case before them is not inconsistent with this Comment's advocacy of a bright line rule for the allocation of the burden. Indeed, the exact nature of remedies, by definition, are virtually always a function of the facts of the particular case. A remedy is "anything a court can do for a litigant who has been wronged or is about to be wronged." ${ }^{135}$ Determining what should be done for the wronged or prospectively wronged litigant then necessarily involves examining the specific circumstances of the dispute. Each of the two most important classes of remedies, damages and injunctions, seeks to craft a solution sensitive to the specific facts of a given dispute. ${ }^{136}$ Compensatory damages are designed to "make plaintiff as well off as he would have been if he never had been wronged." ${ }^{137}$ The fashioning of such a remedy necessarily entails an inquiry into the details of the case at hand. Similarly, injunctions, which are "order[s] from a court to litigants ordering them to do or to refrain from doing some specific thing," ${ }^{138}$ are also a class of remedies requiring an assessment of the case specific facts. This Comment's proposed approach strikes a sensible balance. While courts should determine ex ante the procedural rules allocating the burden of proof, the remedy must account for the salient, case specific facts.

Thus, where the court concludes that the issuing court's judgment is void for lack of personal jurisdiction, a district court may impose tailored conditions on the parties pursuant to the granting of the motion to vacate. Such conditions might include requiring the defendant to accept service of process, ${ }^{139}$ requiring the defendant to bear costs in connection with the default judgment, ${ }^{140}$ or where the defendant's conduct has been particularly obstructionist or evasive, the court, as an

135 Laycock, Modern American Remedies at 1 (cited in note 19).

136 See id (identifying damages and injunctions as flowing from the courts' determination of harm done).

137 Id at 3 .

138 Id.

139 See China Mariners', 1999 US Dist LEXIS 2674 at $* 25$ (conditioning grant of Rule 60(b)(4) motion on defendant's future acceptance of service of process); Triad Energy Corp $v$ McNell, 110 FRD 382,386 (S D NY 1986) (vacating judgment but permitting plaintiff to re-serve defendant through alternate means).

140 See Leab v Streit, 584 F Supp 748, 763 (S D NY 1984) (conditioning the grant of the Rule $60(\mathrm{~b})(4)$ motion on the defendant's assuming the plaintiffs' costs in litigating the motion to vacate and directing plaintiffs to re-serve defendant in the substitute manner designated by the court); Schwab v Bullock's, Inc, 508 F2d 353, 356 (9th Cir 1975) (reversing the district court's denial of the defendant's $60(\mathrm{~b})(4)$ motion to vacate for lack of improper service but instructing the district court to "determine whether in light of the record as a whole the equities demand that [defendant] bear all or a portion of [plaintiff's] expenses in connection with the default judgment, the motion to vacate, and the attendant delay"). 
ancillary remedy ${ }^{141}$ could also issue an attachment ${ }^{142}$ against a portion of the defendant's assets.

Courts adopting the Rockwell rule can mitigate any inequities that might otherwise result from allocating the burden to the plaintiff. This proposed rule is sensible for three main reasons.

\section{Horizontal consistency.}

Courts should adopt this Comment's proposed approach because it fits horizontally with the existing legal rules ${ }^{143}$ for allocating the burden of proof in motions challenging personal jurisdiction under Rules 12 and 55. First, the Rockwell rule fits with the well-established view that plaintiffs bear the burden when their version of the jurisdictional facts is challenged for the first time in a prejudgment motion to dismiss under Rule $12 .^{144}$ In a default judgment, the defendant has not yet challenged the personal jurisdiction of the court; a default necessarily involves a lack of appearance by the defendant. Thus, despite the passage of time, the plaintiff is still in the same relation to the defendant regarding the jurisdictional issue as in a 12 (b) motion. The plaintiff has not yet been forced to prove the court's personal jurisdiction over the defendant. Where possible, it is critical that the court have the opportunity to evaluate the parties' jurisdictional claims with the full benefit of counsel representing both sides of the question. Accordingly, the plaintiff should retain the burden. ${ }^{145}$

Courts adopting the Rohm rule fail to do justice to the command that the plaintiff always offer "events or circumstances that it charac-

141 "Ancillary remedies are designed in aid of other remedies." Laycock, Modern American Remedies at 5 (cited in note 19).

142 An attachment is " $[\mathrm{t}]$ he process of seizing another's property . . . for the purpose of securing satisfaction of a judgment." Black's Law Dictionary at 126 (cited in note 6). See also Laycock, Modern American Remedies at 826 (cited in note 19) (defining an attachment as a "levy or garnishment before judgment").

143 See Edward S. Adams and Daniel A. Farber, Beyond the Formalism Debate: Expert Reasoning, Fuzzy Logic, and Complex Statutes, 52 Vand L Rev 1243, 1283 n 247 (1999) (noting the recent rise in the importance of "horizontal coherence" in the Supreme Court's statutory interpretation methodology).

144 See note 22 and accompanying text. Even the Seventh Circuit, in Bally itself, adopts this proposition. See Bally, 804 F2d at 401 ("[I]t is well established that the plaintiff must prove jurisdiction exists once it is challenged by the defendant.").

145 The importance to our American legal system of ensuring personal jurisdiction limits is well-recognized. See Charles Alan Wright, Arthur R. Miller, and Edward H. Cooper, 15A Federal Practice and Procedure: Jurisdiction \$ 39,11.4 at 422 (West 2d ed 1992) (noting the "intrinsic importance of personal jurisdiction limits"); Stephen J. Safranek, Do Class Plaintiffs Lose Their Constitutional Rights?, 1996 Wis L Rev 263, 265 (recognizing "that personal jurisdiction [is] the touchstone of due process"). It is for this reason that in the context of $60(\mathrm{~b})(4)$ motions, the weighty finality interest yields to the interest of ensuring the court's personal jurisdiction. A final judgment, though final, will not be enforced where it is a "legal nullity" because "the rendering court lacked ... jurisdiction." Carter v Fenner, 136 F3d 1000, 1005 (5th Cir 1998). 
terizes as meeting state statutory and federal due process standards."146 In a motion to vacate a default judgment, the plaintiff has yet to establish personal jurisdiction, and thus, the presumption from Rule 12 should not shift. As a federal appellate court stated in another context, "the party seeking to invoke the jurisdiction of a federal court has the burden of establishing that jurisdiction exists, and the burden may not be shifted to the party challenging the jurisdiction.",147

This Comment's proposed rule is also consistent with the even more analogous rule that the plaintiff bears the burden in opposing motions to set aside the entry of default (as distinguished from default judgment). ${ }^{148}$ This issue, whether or not that burden remains with the plaintiff, is precisely the one at play in determining which party should shoulder the burden of proof in motions opposing default judgments on personal jurisdiction grounds under Rule 60(b)(4). The two provisions for attacking an adverse default are closely related. First, the language in Rules 55 and 60 authorizing relief from entry of default and default judgment is similar. ${ }^{149}$ Second, the two types of attacks occur at nearly the same stage in the litigation process. Both occur after the entry of default but before the defendant has responded to the plaintiff's complaint. Consonant with these parallels between motions to vacate an entry of default and a default judgment, this Comment's proposed approach would make the burden of proof rule the same for the two similar motions.

By placing the burden on the plaintiff to prove jurisdiction when the defendant moves to vacate under Rule 60(b)(4), the proposed rule differs from courts' allocation of the burden for the other Rule $60(\mathrm{~b})$ motions advanced pursuant to $60(\mathrm{~b})(1)-(3)$ and $60(\mathrm{~b})(5)-(6) .^{150}$ This

146 Rockwell, 83 FRD at 559. See also United States $v$ Swiss American Bank, 191 F3d 30, 40 (1st Cir 1999) (describing as "certainly correct" the proposition that "plaintiff[s] ... shoulder the burden of proving personal jurisdiction over the defendant"); In re Vitamins Antitrust Litigation, 120 F Supp 2d 45, 57 (D DC 2000), citing Naartex Consulting Corp v Watt, 722 F2d 779, 785 (DC Cir 1983) ("It is well-established that plaintiffs bear the burden of establishing personal jurisdiction over defendants."). Similarly, in Packard Press Corp v Com Vu Corp, 584 F Supp 73, 76 (E D $\mathrm{Pa}$ 1984), the court emphasized the importance of valid jurisdiction, which justified this burden allocation. In reviewing a 60(b)(4) motion to vacate a default judgment for lack of personal jurisdiction, the court stated that it "has a continuing duty to ensure that such jurisdiction exists before advancing to the merits." Id. "When the court's in personam jurisdiction is challenged by the defendant, the plaintiff must prove that the non-resident defendant's activities in the forum state are sufficient to bring it within the reach of this court's jurisdiction." Id.

147 Product Promotions, Inc v Cousteau, 495 F2d 483, 490 (5th Cir 1974) (examining the reach of 'Texas's long-arm statute).

148 See Part I.B.2.

149 Under Rule 55(c), a court may set aside an entry of default for any "good cause shown." FRCP 55(c). Rule 60(b) also employs a rather open-ended grant of judicial discretion, providing that the reviewing court may relieve a party from a final judgment "upon such terms as are just." FRCP 60(b).

150 See Roberts, Annotation, 59 ALR Fed at 836 (cited in note 5) (noting that in 60(b)(4) 
does not, however, render the proposed rule horizontally inconsistent. As demonstrated, Rule 60(b)(4) motions to vacate a default judgment for lack of personal jurisdiction are functionally similar to Rule 12 motions to dismiss for lack of personal jurisdiction and Rule 55 motions to vacate an entry of default advanced on personal jurisdiction grounds.

While Rule 60(b)(4) attacks are in title similar to the other Rule 60 attacks in that they are motions to vacate default judgments, courts have repeatedly recognized at least three critical functional differences between motions to vacate under Rule 60(b)(4) and other Rule 60 motions. First, a court has no discretion to decline to vacate a judgment once it concludes a judgment is void under Rule 60(b)(4), but courts do have discretion when deciding motions to vacate relying on one of the other Rule 60 subrules. ${ }^{151}$ This distinction goes to the heart of the difference between Rule $60(\mathrm{~b})(4)$ motions and the other 60(b) motions to vacate: to allege that a default is void is to argue that the motions lacks legal validity, but to allege mistake, inadvertence, surprise, or excusable neglect, ${ }^{152}$ newly discovered evidence, ${ }^{153}$ fraud or misrepresentation, ${ }^{154}$ release of the judgment, ${ }^{155}$ or some "other reason justifying relief from the operation of the judgment" ${ }^{\text {, } 156}$ is not to allege that the judgment lacks legal validity, but only that it is based on legal error or requires modification. ${ }^{\text {is }}$

Second, courts have consistently held that unlike motions under Rule 60(b)(1)-(3), there is no time limit for Rule 60(b)(4) motions. ${ }^{1.8}$

Third, and related to the idea that void judgments are per se invalid whereas. objections advanced on the other Rule 60(b) bases are

motions, the burden of proof "may fall on the adversary party, whereas the burden of proof of the other grounds of the motion is typically on the moving party").

151 See id ("The court has no discretion to decline to vacate a default judgment or decree under (4), whereas it does have such discretion where one of the other rules is relied on."). See also Carter v Tenner, 136 F3d 1000, 1005 (5th Cir 1998) (collecting cases); Roberts, Annotation, 59 ALR Fed at $836 \mathrm{n} 7$ (same).

152 FRCP 60(b)(1).

153 FRCP 60(b)(2).

154 FRCP 60(b)(3).

155 FRCP 60(b)(5).

156 FRCP 60(b)(6).

157 See Carter, 136 F3d at 1005 ("Unlike motions pursuant to other subsections of Rule 60(b), Rule 60(b)(4) motions leave no margin for consideration of the district court's discretion as the judgments themselves are by definition legal nullities or not.").

158 See Roberts, Annotation, 59 ALR Fed at 836 n 5 (cited in note 5) (collecting cases). See also Carter, 136 F3d at 1006 ("Motions brought pursuant to Rule 60(b)(4) ... constitute such exceptional circumstances as to relieve litigants from the normal standards of timeliness associated with the rule ... [M]otions brought pursuant to subsection (4) of the rule have no set time limit .... [E]ven the requirement that the motion be made within a 'reasonable time,' which seems literally to apply to motions under Rule 60(b)(4), cannot be enforced with regard to this class of motion."); Orner $v$ Shalala, 30 F3d 1307, 1310 (10th Cir 1994) (noting that there is no time limit for Rule 60(b) motions). 
only an assertion of error, courts have consistently held that defendants moving pursuant to Rule 60(b)(4) need not show a meritorious defense to the action beyond demonstrating the lack of personal jurisdiction. ${ }^{159}$ While Rule 60(b)(4) motions are functionally similar to Rule 12 and Rule 55 motions attacking personal jurisdiction, ${ }^{160}$ $60(b)(4)$ motions are not viewed by courts in tandem with the other subrules of Rule 60; the proposed rule would therefore ensure horizontal consistency in interpretation with the functionally similar federal rules.

Additionally, the proposed rule, unlike the allocation of the burden of proof in most overall causes of action, would allocate the burden of proof to the nonmovant. ${ }^{161}$ However, there are numerous contexts in which courts have held that the nonmovant bears the burden of proof. ${ }^{162}$ Moreover, it is particularly appropriate to assign the burden to the nonmovant given that courts have repeatedly held in the highly analogous Rule 55 context that to do so is proper. ${ }^{163}$ Thus, as a doctrinal matter, the horizontal consistency promoted by the proposed rule may be by itself dispositive. However, several policy-based reasons further support the proposed rule.

\section{Information eliciting.}

The Comment's proposed approach is attractive as a policy matter because it may operate as an information-eliciting rule, permitting courts to give a more searching review of personal jurisdiction. ${ }^{164}$ This dynamic is likely because the allocation of the burden appears to drive

159 See Giraldi $v$ Heep, 1999 US App LEXIS 34309, *6 (4th Cir) (unpublished opinion) ("Unlike the other grounds under Rule 60(b) ... the movant need not establish a meritorious defense."); In re Brackett, 243 BR 910, 914 n 7 (Bankr N D Ga 2000) ("If a judgment is void, no proof is required that the defaulting party has a meritorious defense or that the other party will not be prejudiced by having the judgment set aside."); Roberts, Annotation, 59 ALR at 837 \& 9 (cited in note 5 ).

160 See Part I.B.

161 See McCormick, 2 McCormick on Evidence $\$ 337$ at 428 (cited in note 20) (stating that the burden of proof is generally assigned to the party who "seeks to change the present state of affairs").

162 See, for example, Celotex Corp v Catrett, 477 US 317, 324 (1986) (recognizing that for certain causes of action, "the nonmoving party will bear the burden of proof at trial" and that in the context of summary judgment, where the movant meets a minimum threshold of proof in support of summary judgment, the nonmovant assumes the burden of "go[ing] beyond the pleadings and ... designat[ing] 'specific facts showing that there is a genuine issue for trial"'), quoting FRCP 56(e).

163 See notes 36-44 and the accompanying text.

164 A more searching review is not inconsistent with improved efficiency. By using incentives to increase the likelihood of parties' developing a clear record through the pleadings, the proposed rule may make courts' work in identifying the relevant jurisdictional facts less onerous. Consider China Mariners', 1999 US Dist LEXIS 2674 at *1 n 1 ("The Court's summary of the procedural background ... is made with little help from the parties, who have neglected to provide comprehensive, narrative statements of facts in their memoranda of law."). 
outcomes: of the reported cases where a court evaluating a Rule $60(b)(4)$ motion advanced on grounds of personal jurisdiction both expressly allocated the burden of proof and disposed of the motion on personal jurisdiction grounds, the party bearing the burden of proof has lost over 90 percent of the time. ${ }^{165}$ The allocation of the burden of proof in 60(b)(4) motions advanced on personal jurisdiction grounds may matter tremendously to the parties. Thus, the proposed rule would create an outcome-driven incentive for plaintiffs to identify affirmatively for the reviewing district court evidence of minimum con-

165 These cases were generated by reviewing the set of cases generated by searching in the Westlaw "ALLFEDS" database for "60(b)(4) or 60(B)(4) 'motion to vacate' and burden or proof or prove" and then selecting only those cases which met the following three conditions: (i) the 60 (b)(4) motion was argued on personal jurisdiction grounds; (ii) the court expressly allocated the burden of proof; and (iii) the court disposed of the motion on personal jurisdiction grounds, rather than vacating on a different basis such as one of the other 60(b) subrules concomitantly advanced.

In 23 out of 25 such reported cases, or 92 percent, the allocation of the burden has dictated the outcome; that is, the party bearing the burden of proof on the issue of personal jurisdiction has lost on the 60(b)(4) motion to vacate the default judgment for lack of personal jurisdiction. This phenomenon is evident in both cases where the motion to vacate is granted and where it is denied.

For cases in which the court allocated the burden to the nonmovant and granted the motion to vacate, see Popper, 48 F Supp 2d at 268; Packard Press Corp v Com Vu Corp, 584 F Supp 73 (E D Pa 1984) (granting the 60(b) motion on grounds other than jurisdiction but first recognizing that the nonmovant plaintiff bore the burden of proof on the issue of personal jurisdiction); Donnely, 87 FRD at 80; Rockwell, 83 FRD at 556; DiCesare, 421 F Supp at 116; Southmark San Juan, Inc v Abbas Atash-Sobh, 1994 WL 1031279 (Va Cir Ct 1994). But see Sterling Industrial Corp $v$ Telephone, Inc, 484 F Supp 1294 (W D Mich 1980).

Similarly, for cases allocating the burden to the movant and denying the motion to vacate, see Drexler v Kozloff, 2000 US App LEXIS 67 (10th Cir) (describing district court's order allocating the burden to the defendant and denying the motion to vacate); Bally Export, 804 F2d 398; Jones v Jones, 217 F3d 239 (7th Cir 1954); In re Brackett, 243 BR 910 (N D Ga 2000); Invest l'Inc v ITS International, Inc, 1998 US Dist LEXIS 17915 (N D Ill); Carr v Pouilloux, SA, 947 F Supp 393 (C D Ill 1996); Chase International, Inc $v$ Link and Pan of Texas, Inc, 1995 US Dist LEXIS 11981 (N D Ill); Ocala Waste Disposal Associates v GGC, 1993 US Dist LEXIS 5578 (S D NY); O'Brien Sage Group, Inc, 141 FRD 181 (N D Ill 1992); Miller, 779 F Supp at 207; International Housing Ltd v Rafidain Bank Iraq, 712 F Supp 1112 (S D NY 1989); Schubert's Marine Sales and Service, Inc v M/V Reeter II, 724 F Supp 1229 (N D Ill 1989); Vaughn Products, Inc v Foliage Farms of Mississippi, Inc, 1989 US Dist LEXIS 2953 (N D IlI); Mid-Continent Wood Products, Inc $v$ Harris, 1989 US Dist LEXIS 13109 (N D Ill); International Financial Services v Ross Industries, 1991 US Dist LEXIS 3073 (N D IIl); Triad Energy Corp v McNell, 110 FRD 382 (S D NY 1986); Rohm, 103 FRD at 541; Jardine, Gill \& Duffus, Inc v M/V Cassiopeia, 523 F Supp 1076 (D MD 1981). But see China Mariners', 1999 US Dist LEXIS at 2674.

While only a small number of courts have ruled specifically on the allocation of the burden of proof, courts regularly review parties' (typically defendants') Rule 60(b)(4) motions to vacate a default judgment for lack of personal jurisdiction. Unfortunately, many courts fail to articulate explicitly the controlling burden of proof on the issue. See, for example, Textile Banking Co $v$ Rentschler, 657 F2d 844 (7th Cir 1981) (affirming lower court's denial of a 60(b)(4) motion advanced on personal jurisdiction grounds where neither court articulated a burden of proof); United Bank of Kuwait PLC v Enventure Enhanced Oil Recovery Associates-Charco Redondo Butane, 755 F Supp 1195 (S D NY 1989) (denying motion to vacate without articulating a burden). 
tacts and service of process that serves as the basis for the court's personal jurisdiction.

In contrast, the Rohm rule requires defendants to prove a negative proposition, that the court lacks jurisdiction. Courts and commentators have recognized the difficulties of requiring a party to prove a negative in a number of contexts outside of personal jurisdiction. ${ }^{166}$ Requiring plaintiffs to prove the positive proposition of valid jurisdiction is more likely to elicit the necessary information germane to determining the court's personal jurisdiction. ${ }^{167}$ To meet their burden under the proposed rule, plaintiffs must ensure that the court recognizes the bases for the exercise of its personal jurisdiction. This dynamic may have two additional benefits. First, by increasing the likelihood that courts will be exposed to the key jurisdictional facts, the proposed rule will aid district court judges in fulfilling their "independent, constitutional obligation to protect the jurisdictional limits of the federal courts." ${ }^{168}$ Second, because the proposed rule may elicit a clearer factual basis from plaintiffs regarding personal jurisdiction, the issue of personal jurisdiction will be better illuminated in the record on appeal. ${ }^{1.9}$ While only one circuit court of appeals has expressly addressed the issue of which party has the burden of proof on Rule 60(b)(4) motions, ${ }^{170}$ courts of appeals are fairly regularly confronted with review of district courts' disposition of such motions."

166 See Sean M. Moran, Note, The Presumption of Correctness: Should the Commissioner Be Required to Carry the Initial Burden of Production?, 55 Fordham L Rev 1087, 1097 (1987) (noting that a number of circuit courts of appeals have held that, in the context of income tax law, the initial burden of production is best placed on the Internal Revenue Service because, otherwise, the taxpayer is placed in the difficult position of proving the nonexistence of unreported income); J. Hoult Verkerke, Legal Regulation of Employment Reference Practices, $65 \mathrm{U}$ Chi L Rev $115,167-68$ (1998) (noting that it is more difficult for employers to determine negative information about prospective employees than it is for employers to determine positive information).

167 Rule $60(\mathrm{~b})(4)$ caselaw suggests that parties may need procedural incentives to present courts with the full story. While it is difficult as an empirical matter to know whether courts typically have valid personal jurisdiction over defendants challenging under Rule 60(b)(4), the fact that courts do with some regularity grant the motion suggests that some percentage of the cases have merit.

168 Hertzog, Calamari \& Gleason v Prudential Ins Co, 933 F Supp 246, 249 (S D NY 1996). See also note 145 .

169 See, for example, Enron Oil Corp v Diakuhara, 10 F3d 90, 96 (2d Cir 1993) ("[T]he importance of an explanation by the district court for its denial of a motion to vacate ... is selfevident. The absence of an explanation defeats intelligent appellate review."); General Contracting, 899 F2d at 115-16 (criticizing the district court for placing the burden of proof on the defendant and stating "[i]t is impossible, on this chiaroscuro record, to state with any assurance whether or not the court had jurisdiction").

170 See Bally, 804 F2d at 401.

171 For recent examples, see Girardi v Heep, 1999 US App LEXIS 34309, *3 (4th Cir) (unpublished opinion) (reviewing appeal based on lack of notice argument pursuant to 60(b)(4)); Mehdipour v City of Oklahoma City, 1999 US App LEXIS 3455 (10th Cir) (unpublished opinion); Carter v Fenner, 136 F3d 1000, 1003 (5th Cir 1998); Wilmer v Board of County Commissioners of Leavenworth County, 69 F3d 406, 410 (10th Cir 1995); Sea-Land Service, Inc v Ceramica 
3. Fairness, comity, and resolution of disputes in a single proceeding.

Finally, as a matter of policy, the proposed rule promotes fairness. Defendants following the wait and challenge tactic assume significant strategic risks independent of the burden of proof. If the defendant loses on the jurisdictional issue in that procedural posture, the defendant waives the right to defend on the merits. ${ }^{172}$ Moreover, in cases where the defendant waits until the court of registration begins enforcement of the default judgment by attaching the defendant's assets, the defendant risks subjecting its assets to the judicial process even if the judgment eventually proves to be void. ${ }^{173}$

By adopting the Rockwell rule but using the remedy to account for any unfairness, this Comment's proposed rule strikes the right balance by avoiding the additional burden of extra risk on the defendant through the loss of the advantageous burden of proof. There are several potential problems of unfairness with allocating the burden of proof to the plaintiff. First, the Rohm court's comment that it is "not unfair" to place the burden on the defendant where the defendant knows of the original suit but declines to appear ${ }^{174}$ may be premised on the fear that if the allocation of the burden of proof to the plaintiff is maintained, defendants will successfully avoid the requirements of litigation and suffer no adverse consequences from the default. However, as the two types of risk discussed above show, this assumption is faulty; thus the Rohm court's concern is overstated. A second concern predicated on fairness is the potential loss of evidence. Where many years have passed since the default judgment, there is a valid fear of "prejudice against a plaintiff who, owing to delay, might in subsequent collateral proceedings no longer have evidence of personal jurisdiction that existed at the time of the underlying suit."

Europa II, Inc, 160 F3d 849, 852 (1st Cir 1998).

172 See Practical Concepts Inc v Republic of Bolivia, 811 F2d 1543, 1547 (DC Cir 1987). See also Restatement (Second) of Judgments $\S 65 \mathrm{cmt} \mathrm{b}$ (1982) ("When [a defendant knows] about the action but perceive[s] that the court lack[s] . . jurisdiction, he is given a right to ignore the proceeding at his own risk.").

173 See, for example, Practical Concepts v Republic of Bolivia, 613 F Supp 863, 865 (D DC 1985) (noting that although the defendant, Bolivia, acknowledged service of the complaint, its counsel did not appear in the action until over one month after the Court issued attachments to several United States banks against Bolivian embassy accounts), revd on other grounds, 811 F2d 1543. The risks presented by the prospect of an attachment are significant. See Laycock, Modern American Remedies at 827 (cited in note 19) (noting the "disruptive impact of the attachment" when a business faces an attachment against its "operating funds, or the inventory available for sale, or the equipment used to manufacture or deliver the product").

174 Rohm, 103 FRD at 544.

175 Miller, 779 F Supp at 210-11. 
Additionally, shouldering the plaintiff with the burden of proof may infringe on the plaintiff's interest "in the choice of forum." Where the plaintiff is forced to litigate in the district of the court of registration in order to seek collection of the judgment, this infringement may translate into significant costs to the plaintiff. This Comment's proposed rule, however, permits courts to account for any such problems by attaching conditions in cases where the court grants the motion to vacate. A court may attach such conditions as requiring that the defendant stipulate to service of process where the defendant's delay has caused the loss of evidence. ${ }^{177}$ Additionally, where the defendant's delay has caused the plaintiff to expend great resources, courts may grant the motion with the condition that the defendant pay the plaintiff's attorney's fees. ${ }^{178}$ Moreover, in extreme cases of defendants' evasiveness, the court may hold out the specter of an ancillary remedy of attachment to enforce the defendant's cooperation. ${ }^{179}$

The Miller court articulated two additional policy interests that may militate against the Rockwell rule. First was "the concerns of comity among the district courts of the United States." point is valid, it is of limited force. The rule that a judgment issued without valid personal jurisdiction is void also infringes, in a sense, on comity among district courts whenever one court voids the judgment of another. Nonetheless, that rule is beyond reproach. ${ }^{181}$ Second, the court in Miller pointed to "the interest in resolving disputes in a single judicial proceeding." pose this interest may be important, by the time a plaintiff has obtained an entry of default, a default judgment, and then registered that judgment in one or more judicial districts, the dispute has already encompassed several proceedings. The damage to the interest in resolving disputes in a single proceeding has been inflicted before any rules concerning the allocation of the burden of proof on the motion to vacate take effect. Thus, the allocation of the burden of proof to the plaintiff will have, at best, marginal impact on the systemic interests of comity and finality.

176 Id at 210.

177 For examples of courts attaching conditions to the grant of a $60(b)(4)$ motion to vacate for lack of personal jurisdiction, see notes $139-40$.

178 See, for example, Schwab v Bullock's Inc, 508 F2d 353, 356 (9th Cir 1974) (ordering district court on remand to consider whether defendant should bear plaintiff's costs associated with default judgment and motion to vacate).

179 See notes 140-41 and accompanying text.

180 Miller, 779 F Supp at 210.

181 See the cases cited in note 7 and accompanying text.

$182779 \mathrm{~F}$ Supp at 210. 


\section{CONCLUSION}

Courts should adopt the Rockwell rule allocating the burden of proof to the plaintiff in Rule 60(b)(4) motions to vacate a default judgment as void for lack of personal jurisdiction. In adopting this rule, courts should reject the recent trend embodied by Rohm and the two outlier approaches. However, courts should condition the remedy to mitigate any prejudice resulting from this allocation of the burden. This Comment's proposed rule is doctrinally attractive because it promotes horizontal consistency across analogous motions advanced under Rules 12,55 , and 60 , and normatively attractive because it provides notice, promotes efficiency, elicits information, and ensures fairness. By adopting this Comment's proposed rule, federal courts could move away from the current conflict and towards a consistent, sensible rule. 


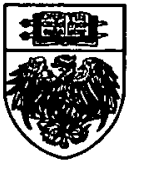

